\title{
Effect of pre-gelatinized temperature on physical and nutritional content of indonesian instant cassava leaves porridge: rowe luwa
}

\section{Efeito da temperatura de pré-gelatinizada no conteúdo físico e nutricional do mingau instantâneo de folhas de mandioca: rowe luwa, típico da Indonésia}

\author{
Ade Chandra Iwansyah ${ }^{1 *}$ (D),Trian Apriadi ${ }^{2}$, Dede Zainal Arif ${ }^{2}$, Yusuf Andriana ${ }^{1}$, \\ Ashri Indriati ${ }^{3}$, Nurkartika Indah Mayasti ${ }^{3}$, Rohmah Luthfiyanti ${ }^{3}$ \\ ${ }^{1}$ National Research and Innovation Agency, Research Unit for Natural Product Technology, \\ Yogyakarta/Gunungkidul - Indonesia \\ ${ }^{2}$ Pasundan University, Faculty of Enginering, Department of Food Technology, Bandung/West Java - Indonesia \\ ${ }^{3}$ National Research and Innovation Agency, Research Center for Appropriate Technology, Subang/West Java - \\ Indonesia
}

${ }^{*}$ Corresponding Author: Ade Chandra Iwansyah, National Research and Innovation Agency, Research Unit for Natural Product Technology, JI, Jogja, Wonosari km 31,5 Kab, 55861, Yogyakarta/Gunungkidul - Indonesia, e-mail: chandra.iwansyah@gmail.com

Cite as: Iwansyah, A. C., Apriadi, T., Arif, D. Z., Andriana, Y., Indriati, A., Mayasti, N. U., \& Luthfiyanti, R. (2022) Effect of pre-gelatinized temperature on physical and nutritional content of indonesian instant cassava leaves porridge: rowe luwa. Brazilian Journal of Food Technology, 25, e2021050. https://doi.org/10.1590/1981-6723.05021

\begin{abstract}
Rowe luwa is a traditional porridge from Southwest Sumba, Indonesia, made from the steamed pulp cassava leaves pounded together with rice. This study examined the effect of pre-gelatinization temperature on the physical quality and nutritional content of instant rowe luwa porridge. The experimental design used in this study was a Completely Randomized Design (CRD) with pre-gelatinization temperature factors, viz., $60^{\circ} \mathrm{C}\left(\mathrm{X}_{1}\right), 65^{\circ} \mathrm{C}\left(\mathrm{X}_{2}\right), 70^{\circ} \mathrm{C}\left(\mathrm{X}_{3}\right), 75^{\circ} \mathrm{C}$ $\left(\mathrm{X}_{4}\right)$ and $80^{\circ} \mathrm{C}\left(\mathrm{X}_{5}\right)$. Physical properties were measured by analyzing color, viscosity, rehydration, and syneresis, while for nutritional compositions, water content, ash, fat, protein, carbohydrate, and energy were evaluated. The simple linear regression was employed to examine the correlation between pre-gelatinization temperature and physical properties or nutritional composition. The results showed that the pre-gelatinization temperature correlated with physical properties, such as: viscosity $(r=0.9924)$, rehydration $(r=0.807)$ and syneresis $(r=0.841)$. Furthermore, the pre-gelatinized temperature significantly affected protein and carbohydrate contents $(p<0.05)$, while the moisture, ash, and fat contents showed negligible effect $(p>0.05)$. Principal Component Analysis (PCA) showed that instant rowe luwa porridge prepared with the pre-gelatinization temperature of $80^{\circ} \mathrm{C}$ (object $\mathrm{X}_{5}$ ) had the highest viscosity, rehydration, syneresis, and protein contents compared to the other cooking temperatures. These preliminary data are useful for further research to determine the method and optimization formula of the instant rowe luwa porridge.
\end{abstract}

Keywords: Drum dryer; Indonesian cassava leaves porridge; Pre-gelatinization. 


\section{Resumo}

Rowe luwa é um mingau tradicional do sudoeste de Sumba, na Indonésia, feito de polpa cozida no vapor de folhas de mandioca triturada junto com arroz. Neste estudo, o efeito da temperatura de pré-gelatinização sobre a qualidade física e o conteúdo nutricional do mingau instantâneo de rowe luwa foi examinado. O desenho experimental utilizado neste estudo foi um desenho completamente aleatório (CRD) com fatores de temperatura de pré-gelatinização, viz., $60{ }^{\circ} \mathrm{C}\left(\mathrm{X}_{1}\right), 65^{\circ} \mathrm{C}\left(\mathrm{X}_{2}\right), 70{ }^{\circ} \mathrm{C}\left(\mathrm{X}_{3}\right), 75^{\circ} \mathrm{C}\left(\mathrm{X}_{4}\right)$ e $80{ }^{\circ} \mathrm{C}\left(\mathrm{X}_{5}\right)$. As propriedades físicas foram medidas através da análise de cor, viscosidade, reidratação e sinérese, enquanto que, para as composições nutricionais, foram avaliados os teores de água, cinzas, gordura, proteína, carboidrato e valor calórico. A regressão linear simples foi empregada para examinar a correlação entre a temperatura de pré-gelatinização e as propriedades físicas ou a composição nutricional. Os resultados mostraram que a temperatura de pré-gelatinização apresenta correlação com propriedades físicas, tais como: viscosidade $(r=0,9924)$, reidratação $(r=0,807)$ e sinérese $(r=0,841)$. Além disso, a temperatura de pré-gelatinização afetou significativamente os teores de proteínas e carboidratos $(p<0,05)$, enquanto que, para os teores de umidade, cinzas e gordura, apresentou efeito desprezível $(p>0,05)$. A análise de componentes principais (PCA) mostrou que o mingau instantâneo de rowe luwa com a temperatura de pré-gelatinização de $80^{\circ} \mathrm{C}$ (objeto X5) apresentou os maiores valores de viscosidade, reidratação, sinérese e conteúdo de proteína, em comparação com as outras temperaturas de cozimento estudadas. Estes dados preliminares são úteis para pesquisas futuras para determinar o método de preparação e a fórmulação otimizada do mingau instantâneo de rowe luwa.

Palavras-chave: Secador de tambor; Mingau de folhas de mandioca indonésio; Pré-gelatinização.

\section{Introduction}

Malnutrition, stunting, and over nutrition are nutritional problems worldwide, especially in poor and developing countries (United Nations International Children's Emergency Fund, 2020). According to the World Health Organization (WHO), Indonesia is among the third countries with the highest prevalence of stunting in Southeast Asia. Based on the basic health research data in 2018, it showed that the prevalence of stunting in the Southwest Sumba regency, East Nusa Tenggara reached $61.2 \%$, exceeding the national stunting condition (Ministry of Health of Indonesia, 2019). The data indicate that the increasing of stunting prevalence in this regency should be a concern of Indonesian government to intervene in a stunting management scheme.

One of the local wisdom foods from Southwest Sumba is rowe luwa porridge. Rowe luwa porridge comes from rowe word, which means leaf, and luwa, which means cassava. Rowe luwa is a green pulp made from cassava leaves pounded together with rice. It can be developed for local food innovation. Moreover, it is expected to provide various foods based on local bio-resources, to support stunting management. Besides, the manufacture of instant rowe luwa aims to extend its product shelf life. Furthermore, drying is a good alternative for its conservation.

Looking at current market trend, consumers prefer instant products or ready to eat products compared to conventional ones. Statistical data on the consumption of instant porridge in Indonesia showed that each year, consumption rate of instant porridge in Indonesia has increased of 31.47\% (2011-2015) (Biro Pusat Statistik, 2016). Instant food, usually in dry or concentrate form, makes it practice to consume and can be served in a short time. According to Mayachiew et al. (2015), some important criteria in instant porridge production are hydrophilic properties, not having an impermeable gel layer, and rehydration of the final product, which does not produce clumping and settling products.

Formulation development is a critical stage in product manufacturing because it will affect to the final product. The mixing process of ingredients in the formulation of rowe luwa porridge will affect the resulting product. According to Makame et al. (2019), the viscosity of instant porridge that has been brewed varied from slightly thick to thick; this is due to the greater concentration of white rice flour addition, the higher 
rice flour addition, the higher of thickness of the instant porridge. Drum drying is a promising alternative to instantization fruit flakes (Nunes et al., 2020).

In instance-based process, pre-gelatinization process is a modification of starch, made through a process involving water and heat to break down all or part of the granules, then dried to produce complete and partial starch pre-gelatinization (Wadchararat et al., 2006; Palguna et al., 2014). Several factors influence this pregelatinization process. Among of them is temperature. Therefore, this study aimed to examine the effect of pre-gelatinization temperature on the physical quality and nutritional content of instant rowe luwa porridge.

\section{Materials and methods}

This research was conducted in June 2020 - April 2021. The research took place at the Indonesian Institute of Sciences (LIPI), Research Center for Appropriate Technology, Subang District, West JavaIndonesia $(-6.554421141915637,107.76218022289622)$ and it will be implemented in the Southwest Sumba Regency, NTT-Indonesia.

\subsection{Materials}

Fresh cassava (Manihot esculenta Crantz) leaves, rice flour, shallots, garlic, salt, salam leaves, lemongrass, ginger, sugar, and coconut milk, were purchased in a traditional market, Subang, Indonesia. Sucrose, $n$-hexane, $\mathrm{CuSO}_{4} .5 \mathrm{H}_{2} \mathrm{O}, \mathrm{H}_{2} \mathrm{SO}_{4},\left(\mathrm{NH}_{4}\right)_{2} \mathrm{HPO}_{4}, \mathrm{HCl}, \mathrm{Na}_{2} \mathrm{CO}_{3}, \mathrm{KIO}_{3}$, and $\mathrm{NaOH}$ were obtained from Sigma-Aldrich, Singapore. Citric acid, distillated water, starch, phenolphthalein 1\%, LuffSchoorl's solution and Pb-acetate were taken from the chemical stockroom at Research Center for Appropriate Technology, Indonesian Institute of Sciences (LIPI). All reagents were analysis grade.

\subsection{Preparation of samples}

Young cassava leaves, $\pm 4-6$ months, trimmed to cut the leaves and stalks. Cassava leaves $(10.59 \%)$, rice flour $(5.30 \%)$, bay leaves $(0.34 \%)$, shallots $(1.01 \%)$, garlic $(0.67 \%)$, lemongrass $(0.84 \%)$, ginger $(0.84 \%)$, salt $(0.34 \%)$, sugar $(0.41 \%)$, coconut milk (5.04\%), and water (74.61\%) were weighed. Cassava leaves and rice flour were crushed using a chopper (Philips HD 3115, China). Then, the ingredients were mixed and cooked with cooking temperatures of $60^{\circ} \mathrm{C}\left(\mathrm{X}_{1}\right), 65^{\circ} \mathrm{C}\left(\mathrm{X}_{2}\right), 70{ }^{\circ} \mathrm{C}\left(\mathrm{X}_{3}\right), 75^{\circ} \mathrm{C}\left(\mathrm{X}_{4}\right)$, and $80{ }^{\circ} \mathrm{C}\left(\mathrm{X}_{5}\right)$ for 40 minutes. The slurry dough was then dried using a drum dryer at temperature of $115-120^{\circ} \mathrm{C}$, with a rotating speed of $8 \mathrm{~Hz}$. The dry rowe luwa porridge was then mashed using a chopper and sieved to a size of $60 \mathrm{mesh}$. Finally, instant rowe luwa porridge was packaged and ready to be analyzed.

\subsection{Procedure of analyses}

\subsubsection{Viscosity measurement}

A Rapid Visco Analyser (RVA-Techmaster, Macquarie Park, Australia), interfaced with a personal computer equipped was used to measure the viscosity of instant rowe luwa porridge (Amagloh et al., 2013).The samples were weighed $3 \mathrm{~g}$ and then mixed with $25 \mathrm{~mL}$ of distilled water in an aluminum container. The sample was then put into the Rapid Visco Analyzer with a rotation speed of $100 \mathrm{rpm}$ at $25{ }^{\circ} \mathrm{C}$ for 2 minute. The sample was then heated to $95^{\circ} \mathrm{C}$ in 5 minutes, then held at $95^{\circ} \mathrm{C}$ for 3 minutes. After that, the samples were again cooled to $50^{\circ} \mathrm{C}$ in 4 minutes and then held at $50{ }^{\circ} \mathrm{C}$ for 2 minutes.

\subsubsection{Color analysis}

The color of rowe luwa instant porridge samples were observed using high-quality colourimeter NH 310 (Indriati et al., 2020). The analysis methods used were CIE (Commission Internationale de L'Eclairage) 
$L^{*} a^{*} b^{*}$ and hue coordinates. Coordinate $L^{*}$ represents the clarity, in which $\mathrm{L}=0$ is black, and $L^{*}=100$ is colourless. Coordinate $a^{*}$ represents the shade of red and green, in which $a^{*}>0$ indicates red colour and $a^{*}<0$ means green colour. Coordinate $b^{*}$ represents the tone of blue and yellow, in which $b^{*}>0$ shows the intensity of yellow and $b^{*}<0$ indicates the hue of blue. The hue $\left(h^{*}\right)$ is the characteristics of the colour, i.e. red, yellow, green, and blue.

\subsubsection{Rehydration}

To determine the rehydration of instant rowe luwa porridge, an amount of $1 \mathrm{~g}$ of sample instan rowe luwa porridge was weighed and then soaked in hot water. The rehydration was carried out at $95{ }^{\circ} \mathrm{C}(10 \mathrm{~min})$ in water bath filled with distilled water. Then, centrifugation $(300 \mathrm{rpm})$ was carried out for 25 minutes. Each sample was filtered from the water, and weighed. The final moisture content of instant rowe luwa porridge after reconstitution was determined according to AOAC standards (Zielinska \& Markowski, 2012). Each measurement was carried out in triplicate.

\subsubsection{Syneresis}

Rowe luwa porridge suspension $(5 \%, \mathrm{w} / \mathrm{w})$ was heated at $90{ }^{\circ} \mathrm{C}$ for $30 \mathrm{~min}$ in a temperature-controlled water bath, followed by rapid cooling in an ice water bath to room temperature. Then, the sample was stored for 24 hours at $4{ }^{\circ} \mathrm{C}$. Syneresis (\%) was measured as amount of water released after centrifugation at $3200 \mathrm{X} \mathrm{g}$ for 15 minutes (Singh et al., 2006; Li et al., 2016).

\subsubsection{Nutritional composition}

Nutritional compositions viz., protein, moisture, fat, ash, carbohydrate of instant rowe luwa porridge were determined (Association of Official Agricultural Chemists, 2004). Moisture and ash contents were determined by using the gravimetric method (Association of Official Agricultural Chemists, 2004). The Buchi-Dumaster equipment was used to measure the protein content (Association of Official Agricultural Chemists, 2004), while fat was measured by the Weibull method (Association of Official Agricultural Chemists, 2004), and carbohydrates were calculated (Association of Official Agricultural Chemists, 2004). The energy value of instant rowe luwa porridge was calculated by the At-water factor $(1 \mathrm{~g}$ protein $=4 \mathrm{kcal}$; $1 \mathrm{~g}$ fat $=9 \mathrm{kcal}$; and $1 \mathrm{~g}$ carbohydrate $=4 \mathrm{kcal})$.

\subsection{Statistical analysis}

Data were presented as mean \pm standard deviation $(\mathrm{sd})(\mathrm{n}=3)$. Normality test was carried out on the data, and Analysis of Variance (ANOVA) was used to determine the significantly differences between treatments. Simple linear regression and principal component analysis (PCA) were used to evaluate the relationship between the pre-gelatinization temperature and the physicochemical properties of instant rowe luwa porridge. Statistical analysis was performed using Microsoft Excel 2013 and XL-STAT Statistical Software.

\section{Results and discussion}

\subsection{Color}

The effect of pre-gelatinization temperature on the color of the instant rowe luwa porridge is presented in Table 1 . The statistical analysis results showed that the pre-gelatinization temperature significantly affected the $* a$ and $* b$ values of instant rowe luwa porridge $(p<0.05)$ but had not significantly impact on the $* L$ and hue values $(p>0.05)$. 
Effect of pre-gelatinized temperature on physical and nutritional content of indonesian instant cassava leaves porridge: rowe luwa Iwansyah et al.

Table 1. The results of color analysis of instant rowe luwa porridge based on pre-gelatinization temperature treatment.

\begin{tabular}{ccccc}
\hline Temperature $\left({ }^{\circ} \mathbf{C}\right)$ & ${ }^{*} \boldsymbol{L}$ & ${ }^{*} \boldsymbol{a}$ & ${ }^{*} \boldsymbol{b}$ & hue \\
\hline $60\left(\mathrm{X}_{1}\right)$ & $45.141 \pm 0.001$ & $0.766 \pm 0.022^{\mathrm{de}}$ & $7.230 \pm 0.014^{\mathrm{bcd}}$ & $7.271 \pm 0.012$ \\
\hline $65\left(\mathrm{X}_{2}\right)$ & $44.710 \pm 0.007$ & $1.322 \pm 0.016^{\mathrm{a}}$ & $7.683 \pm 0.014^{\mathrm{a}}$ & $7.796 \pm 0.014$ \\
\hline $70\left(\mathrm{X}_{3}\right)$ & $44.412 \pm 0.004$ & $0.875 \pm 0.008^{\mathrm{bc}}$ & $7.237 \pm 0.015^{\mathrm{bcd}}$ & $7.290 \pm 0.002$ \\
\hline $75\left(\mathrm{X}_{4}\right)$ & $44.423 \pm 0.006$ & $0.783 \pm 0.017^{\mathrm{de}}$ & $7.197 \pm 0.171^{\mathrm{bcd}}$ & $7.341 \pm 0.013$ \\
\hline $80\left(\mathrm{X}_{5}\right)$ & $43.912 \pm 1.154$ & $0.766 \pm 0.026^{\mathrm{bc}}$ & $5.665 \pm 0.033^{\mathrm{e}}$ & $6.063 \pm 0.545$ \\
\hline
\end{tabular}

Data are presented as mean \pm standard deviation $(s d)(n=3) . a>b>c>d>e$. Values in the same column followed by different alphabets are significantly different by Duncan's test $(p<0.05)$.

The values of $* a$ and $* b$ instant porridge of rowe luwa were $0.77-1.32$ and 5.66 to 7.68 , respectively (Table 1). Generally, the * $a$ and $* b$ values of instant rowe luwa porridge with a pre-gelatinization temperature treatment of $80^{\circ} \mathrm{C}\left(\mathrm{X}_{5}\right)$ were the highest. This findings show that the pre-gelatinization temperature treatment causes a reddish image with a yellowish intensity which is thought to be due to a non-enzymatic browning reaction during the cooking process (pre-gelatinization). These results were agreement with Wijanarka et al. (2017) that reported the enzymatic reaction more retarded with the longer pre-gelatinized time of Gayam (Inocarfus fagifer Forst.) flour. Furthermore, the longer pre-gelatinization time also would increase the temperature and deactivate polyphenol oxidase (Akyıldız \& Ocal, 2006).

\subsection{Viscosity}

The linear regression graph in viscosity analysis; the correlation coefficient $(r)$ and determination coefficient $\left(R^{2}\right)$ are shown in Figure 1. The results obtained showed a relationship between pre-gelatinization temperature and viscosity. These results showed that the value of the correlation coefficient $(r)$ and the coefficient of determination $\left(R^{2}\right)$ were 0.9924 and 0.9849 , respectively.

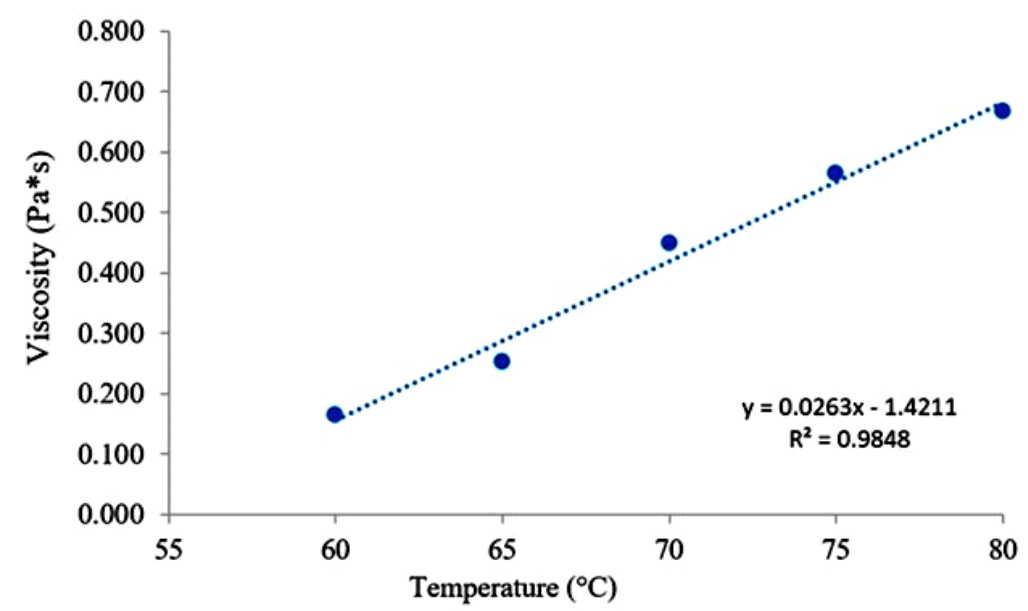

Figure 1. Viscosity value of instant rowe luwa porridge based on pregelatinization temperature treatment. Data are presented as mean \pm standard error $(n=3)$.

The average viscosity of the instant rowe luwa porridge were 0.165 to $0.667 \mathrm{~Pa}^{*} \mathrm{~s}$ (Figure 1). All pregelatinization temperature treatments showed an increasing in viscosity proportional with temperature. The lowest viscosity is at the cooking temperature of $65^{\circ} \mathrm{C}\left(0.165 \mathrm{~Pa}^{*} \mathrm{~s}\right)$, while the highest viscosity is at the cooking temperature of $80{ }^{\circ} \mathrm{C}\left(0.667 \mathrm{~Pa}^{*} \mathrm{~s}\right)(p<0.05)$. This condition occurred might because the starch contained in the instant rowe luwa porridge have gelatinization due to the influence of cooking temperature. 
These results were in agreement with Singh et al. (2006), which reported that when heated the granules will inflation because they absorb water. Furthermore, it undergoes gelatinization and results in increased viscosity. Muchlisyiyah et al. (2020) reported that increase time and temperature have increased gel consistency. Pre-gelatinization has increased the thickness of red glutinous rice flour. Rice flour heated in a longer period has higher viscosity and could be attributed by lower water content (Rohaya et al., 2013).

The increase in viscosity is caused by the inflation of starch granules, especially amylose (Donald, 2004; Palguna et al., 2014). According to Sopade et al. (1992), when the temperature is low, the starch is pregelatinized so that it is easy to absorb air, causing the granules to expand and increase the viscosity. At the gelatinization temperature, the viscosity increase is due to the amylose diffusing the granules to produce a gel. This increase continued until the viscosity peaked, after which the viscosity of the un-gelatinated decreased. It is based on the breakdown of the rice grains and gel structure, with the system turns into a mixture of leached amylose molecules, melted amylopectin sites, and granular fragments (Han \& Hamaker, 2001; Wijanarka et al., 2017).

\subsection{Rehydration}

The linear regression graph in rehydration analysis; the correlation coefficient $(r)$ and determination coefficient $\left(R^{2}\right)$ are shown in Figure 2. Figure 2 showed a relationship between pre-gelatinization temperature and rehydration. These results showed that the value of the correlation coefficient $(r)$ and the coefficient of determination $\left(R^{2}\right)$ were 0.9761 and 0.9529 , respectively.

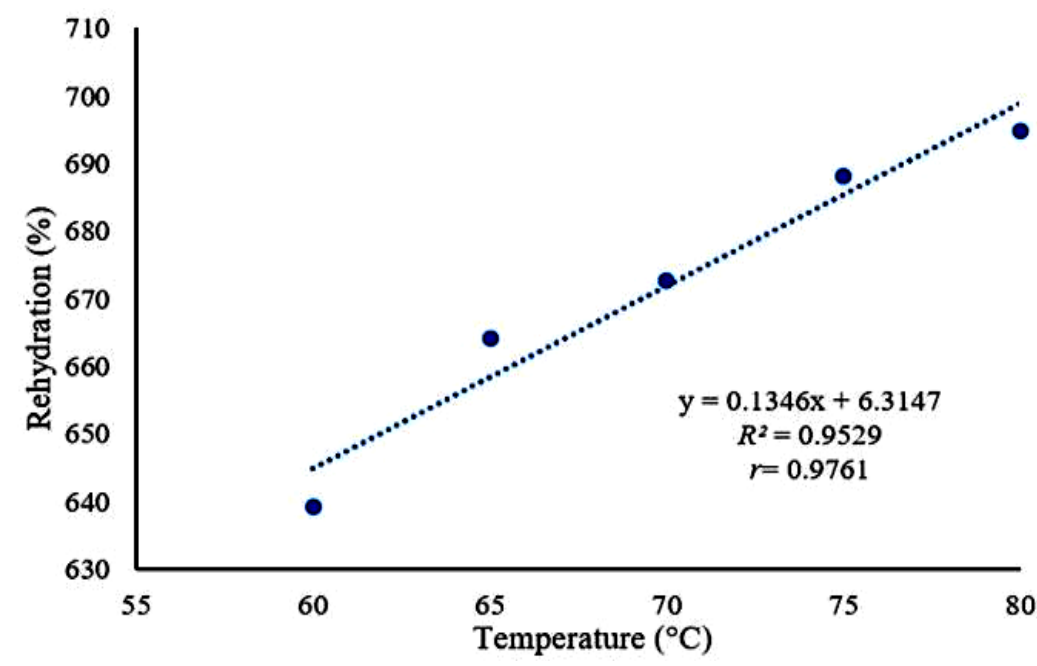

Figure 2. Rehydration value of instant rowe luwa porridge based on pregelatinization temperature treatment. Data are presented as mean \pm standard error $(n=3)$.

Figure 2 shows that the higher the pre-gelatinization temperature, the more of rehydration value increases. The instant rowe luwa porridge with pre-gelatinization temperature $65^{\circ} \mathrm{C}\left(\mathrm{X}_{1}\right)$ had the lowest rehydration values (639.41\%), while the instant rowe luwa porridge with pre-gelatinization temperature $80^{\circ} \mathrm{C}\left(\mathrm{X}_{5}\right)$ had the highest rehydration values $(694.72 \%)(p<0.05)$. This increase is probably due to the gelatinization process during the rehydration process. The cell walls will absorb air and soften when the dry material is rehydrated. With elasticity in the cell wall, the cell wall will return to its original shape. These agreed with Awuchi et al. (2019) that at 60 ${ }^{\circ} \mathrm{C}$, the starch granules begin to absorb the liquid and swell. At $80^{\circ} \mathrm{C}$, the granules will have absorbed five times their volume until they burst open, thus releasing starch into the liquid. Gelatinization is completely achieved when the liquid reaches $100^{\circ} \mathrm{C}$. Furthermore, Puspitowati \& Driscoll (2007) that showed the rate of rehydration of rice increases with the degree of gelatinization and the final moisture content. The pre-cooked starch granules swell faster than the ungelatinized rice. The rise of the rehydration rate is like viscosity. Pre-cooked rice 
viscosity was observed before the gelatinization temperature. The more significant the water absorption of the instant porridge, the more readily it dissolves in the pulp and makes it more accessible during the manufacturing process (Amagloh et al., 2013; Onyango et al., 2020).

\subsection{Syneresis}

Syneresis (\%) was defined as the starch pastes freeze-thaw stability, which indicates the percentage of water separated after the starch paste was treated by freezing storage (Haryanti et al., 2014). Syneresis is a separation between starch gel and water (Ariyantoro et al., 2020). The linear regression graph in rehydration analysis; the correlation coefficient $(r)$ and determination coefficient $\left(R^{2}\right)$ are shown in Figure 3.

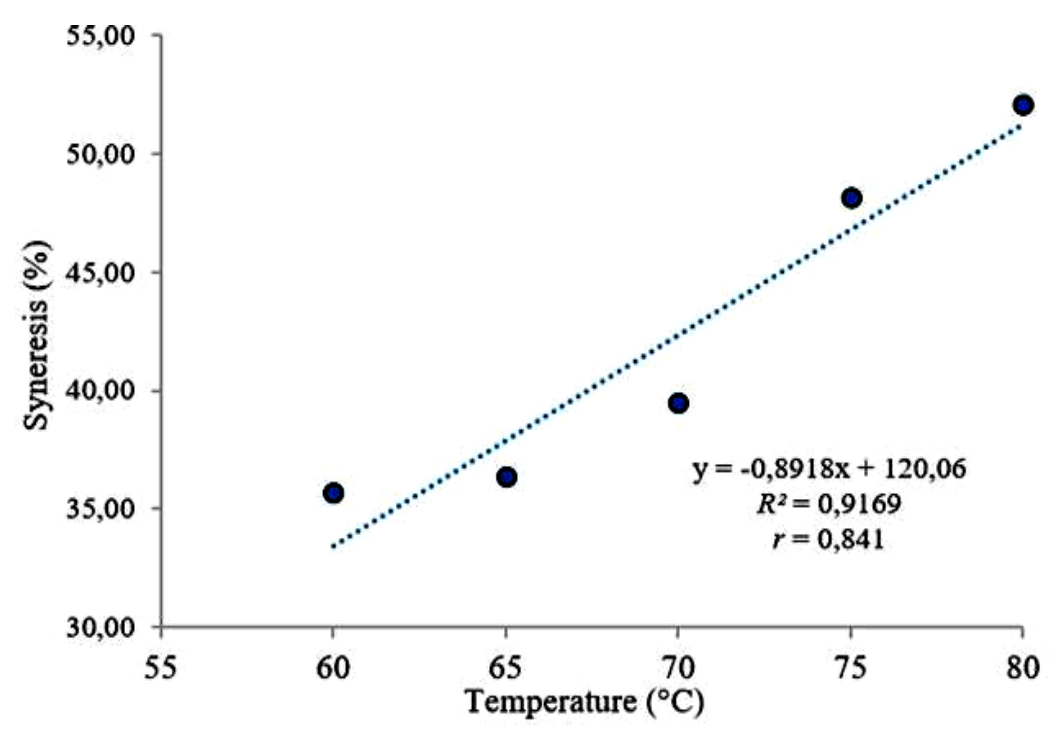

Figure 3. Syneresis value of instant rowe luwa porridge based on pregelatinization temperature treatment. Data are presented as mean \pm standard error $(n=3)$.

Figure 3 shows a relationship between pre-gelatinization temperature and rehydration with values of the correlation coefficient $(r)$ and the coefficient of determination $\left(R^{2}\right)$ were 0.841 and 0.9169 , respectively. The higher the pre-gelatinization temperature, the higher the syneresis value has increased $(p<0.05)$. The instant rowe luwa porridge with pre-gelatinization temperature $65^{\circ} \mathrm{C}\left(\mathrm{X}_{1}\right)$ had the lowest syneresis values $(35.69 \%)$, while the instant rowe luwa porridge with pre-gelatinization temperature $80^{\circ} \mathrm{C}\left(\mathrm{X}_{5}\right)$ had the highest syneresis values $(52.11 \%)$. This indicates that the $\mathrm{X}_{5}$ treatment produces high-amylose starch, which is less stable to frozen storage than the other treatments. This results was in agreement with Denchai et al. (2019), that reported the retrograded rice starch gelatinized at the incomplete gelatinization temperature $\left(77^{\circ} \mathrm{C}\right)$ had the highest percent syneresis than the retrograded rice starch at $95{ }^{\circ} \mathrm{C}$ and $121^{\circ} \mathrm{C}$. At the lowest temperature $\left(77^{\circ} \mathrm{C}\right)$, syneresis increased sharply the following temperature. While a little syneresis was found in starch gels gelatinized at higher temperatures $\left(95^{\circ} \mathrm{C}\right.$ and $\left.121^{\circ} \mathrm{C}\right)$. The increase in syneresis was contributed to an increase in molecular association between starch chains at reduced temperatures that exclude water from the gel structure (Lan et al., 2017).

Bhat \& Riar (2017), reported that the process of breaking starch granules due to temperature increases causes amylose molecules to come out of the granules. The higher the temperature, the more amylose molecules that will come out of the starch granules. Syneresis is caused by the retrogradation of amylose (Singh et al., 2006). The strong bonds between amylose during retrogradation cause more water to separate from the starch gel when the starch gel is put at room temperature. The discharge of large amounts of water during the retrogradation process causes high syneresis (Bhat \& Riar, 2017). 


\subsection{Nutritional composition}

Heat treatment can affect micronutrient in foodstuff (Francisquini et al., 2020). Effects of pregelatinization temperature to nutritional composition of instant rowe luwa porridge is shown at Table 2. Table 2 shows that the pre-gelatinization temperature treatment of instant rowe luwa porridge had a significant effect on protein and carbohydrate content $(p<0.05)$, meanwhile, it had no significant impact on moisture, ash, and fat content $(p>0.05)$. Table 2 shows that the instant rowe luwa porridge with pre-gelatinization temperature $60{ }^{\circ} \mathrm{C}\left(\mathrm{X}_{1}\right)$ and $80{ }^{\circ} \mathrm{C}\left(\mathrm{X}_{5}\right)$ had the highest protein value $(16.54 \%)$, and the lowest of carbohydrates content $(56.58 \%)$. The interaction between starch and protein in food systems increased the gel strength, which was attributed to the increase in the density of protein matrix and formation of elastic starch globules (Couto et al., 2012; Jamilah et al., 2009).

Table 2. Nutritional composition of instant rowe luwa porridge based on pregelatinization temperature treatment.

\begin{tabular}{cccccc}
\hline \multirow{2}{*}{ Constituent } & \multicolumn{5}{c}{ Temperature $\left({ }^{\circ} \mathbf{C}\right)$} \\
\cline { 2 - 6 } & $\mathbf{6 0}\left(\mathbf{X}_{\mathbf{1}}\right)$ & $\mathbf{6 5}\left(\mathbf{X}_{\mathbf{2}}\right)$ & $\mathbf{7 0}\left(\mathbf{X}_{\mathbf{3}}\right)$ & $\mathbf{7 5}\left(\mathbf{X}_{\mathbf{4}}\right)$ & $\mathbf{8 0}\left(\mathbf{X}_{\mathbf{5}}\right)$ \\
\hline Moisture (\%) & $6.50 \pm 0.20$ & $6.50 \pm 0.40$ & $6.57 \pm 0.20$ & $6.55 \pm 0.39$ & $6.78 \pm 0.15$ \\
\hline Ash (\%) & $5.49 \pm 0.25$ & $5.57 \pm 0.31$ & $5.54 \pm 0.13$ & $5.50 \pm 0.32$ & $5.24 \pm 0.19$ \\
\hline Fat (\%) & $14.46 \pm 0.37$ & $14.92 \pm 0.46$ & $14.99 \pm 0.29$ & $15.23 \pm 0.81$ & $14.86 \pm 0.59$ \\
\hline Protein (\%) & $16.34 \pm 0.41^{\mathrm{ab}}$ & $14.11 \pm 0.23^{\mathrm{e}}$ & $14.86 \pm 0.09^{\mathrm{cd}}$ & $15.35 \pm 0.35^{\mathrm{cd}}$ & $16.54 \pm 0.44^{\mathrm{ab}}$ \\
\hline Carbohydrates (\%) & $57.21 \pm 0.50^{\mathrm{cd}}$ & $58.91 \pm 0.78^{\mathrm{ab}}$ & $58.04 \pm 0.33^{\mathrm{ab}}$ & $57.36 \pm 0.23^{\mathrm{cd}}$ & $56.58 \pm 1.17^{\mathrm{e}}$ \\
\hline Energy (kcal) & $424.33 \pm 1.97$ & $426.33 \pm 3.27$ & $426.47 \pm 2.26$ & $427.97 \pm 5.24$ & $426.22 \pm 2.91$ \\
\hline
\end{tabular}

Data are presented as mean \pm standard deviation (sd) $(n=3)$. Values in the same rows followed by different alphabets are significantly different by Duncan's test $(p<0.05)$.

\subsection{Principal Component Analysis (PCA)}

A principal component analysis was used to classify samples and find variables, viz., proximate composition and physical properties of instant rowe luwa porridge that will contribute to differentiation. Based on the theoretical arguments of PCA as described by (Hair et al., 2005), the significant factor loading values higher than or equal 0.7 were used to identify the most important variables and observations in each dimension, or principal components. The first two factors (F1 and F2) accounted for $46.01 \%$ and $21.97 \%$, respectively. The loading factors of $\mathrm{F} 1$ had a positive correlation with color of $* b$ value, hue, viscosity, rehydration and syneresis. The strong positive loadings of F2 are protein, fat and energy. According to Jang et al., (2016), amylose content was positively correlated to pasting temperature, cohesiveness, and protein, but negatively correlated to peak viscosity in japonica and indica rice starches. Figure 4 shows the pregelatinized temperature are differently structured according to their proximate, and physical properties.

At the pre-gelatinization temperature of instant rowe luwa porridge, the physical properties, viz., viscosity, syneresis and rehydration, have a very close positive relationship. Likewise, the protein and carbohydrates content. The viscosity, syneresis, and rehydration values of instant rowe luwa porridge increase with increased temperature. This is in line with what has been reported by Muchlisyiyah et al. (2020), Puspitowati \& Driscoll (2007), and Denchai et al. (2019) that the level of viscosity, synthesis, and rehydration increased with pre-gelatinization temperature.

Figure 4 shows that instant rowe luwa porridge with a pre-gelatinization temperature of $80^{\circ} \mathrm{C}$ (object $\mathrm{X}_{5}$ ) has highest values of viscosity, rehydration, syneresis, and protein value than other objects. Objects $\mathrm{X}_{2}$ and $\mathrm{X}_{3}$ are objects with similar indicators, with the characteristics of the presentation of carbohydrate values, ash content, and color ( $a^{*}$ and $b^{*}$ ). Object $\mathrm{X}_{3}$ with the lowest value of all variables. The $\mathrm{X}_{1}$ and $\mathrm{X}_{4}$ object form their own groups. 


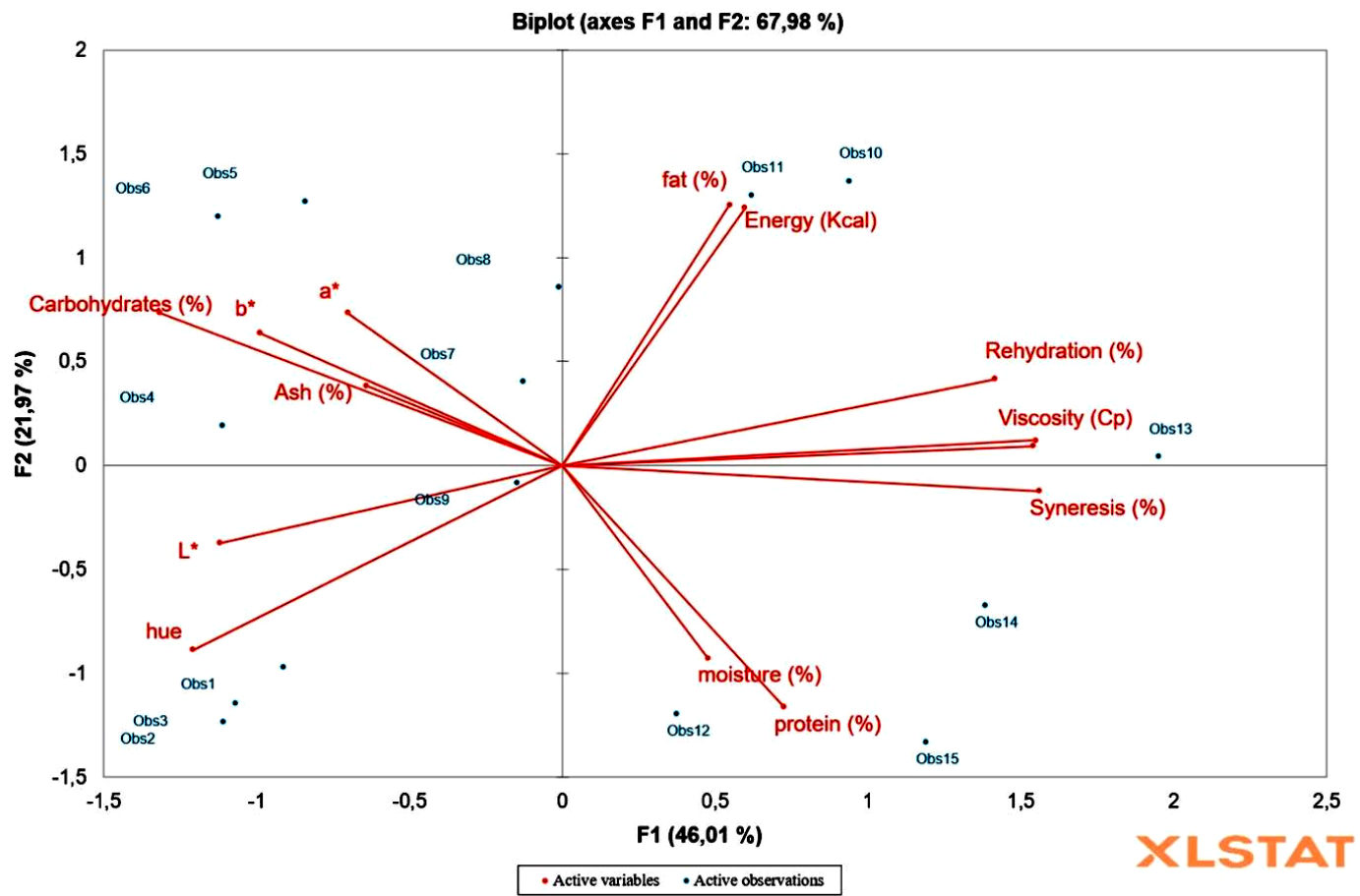

Figure 4. Biplot obtained from PCA of variables comprising proximate, and physical properties.

\section{Conclusion}

In conclusion, the pre-gelatinization temperature affected physical properties, such as viscosity, rehydration, and syneresis of instant rowe luwa porridge. In nutritional composition, the pre-gelatinized temperature had a significant effect on protein and carbohydrate content, while the moisture, ash, and fat content had no significant effect. The viscosity, syneresis, and rehydration values of instant rowe luwa porridge increase with increased temperature. PCA analysis showed the pregelatinized temperature are differently structured according to their proximate, and physical properties. The instant rowe luwa porridge with a pre-gelatinization temperature of $80^{\circ} \mathrm{C}$ (object $\mathrm{X}_{5}$ ) has the highest value of viscosity, rehydration, syneresis, and protein value than other objects. Objects $\mathrm{X}_{2}$ and $\mathrm{X}_{3}$ were objects with similar indicators, with the characteristics of the presentation of carbohydrate values, ash content, and color. Object $\mathrm{X}_{3}$ with the lowest value of all variables. The $\mathrm{X}_{1}$ and $\mathrm{X}_{4}$ object form their own groups.

\section{Acknowledgements}

We are grateful to the Ministry of Financial, Republic of Indonesia for funding the LPDP-Rispro Mandatory-RISTEK/BRIN (No.267/PRN/Stunting/2020), as well as the Indonesian Institute of Sciences (LIPI) for supporting facilities and technical support (ELSA-LIPI). There is no conflict of interest.

\section{References}

Akyıldız, A., \& Ocal, N. D. (2006). Effects of dehydration temperatures on colour and polyphenoloxidase activity of amasya and golden delicious apple cultivars. Journal of the Science of Food and Agriculture, 86(14), 2363-2368. http://dx.doi.org/10.1002/jsfa.2624

Amagloh, F. K., Mutukumira, A. N., Brough, L., Weber, J. L., Hardacre, A., \& Coad, J. (2013). Carbohydrate composition, viscosity, solubility, and sensory acceptance of sweetpotato- and maize-based complementary foods. Food \& Nutrition Research, 57(1), 18717. PMid:23516115. http://dx.doi.org/10.3402/fnr.v57i0.18717

Ariyantoro, A., Parnanto, N. H., \& Kuntatiek, E. (2020). THE effect of various of temperature on physical, chemical and physicochemical properties of yam bean pre-gelatinized flour. Jurnal Teknologi Hasil Pertanian, 8(1), 12-19. http://dx.doi.org/10.20961/jthp.v13i1.40124

Association of Official Agricultural Chemists - AOAC. (2004). Official methods of analysis (15th ed., Vol. 1). Arlington: AOAC Inc. https://doi.org/10.1016/b0-12-765490-9/00006-9 
Awuchi, C.G., Somtochukwu, V., \& Kate, C. (2019). The functional properties of foods and flours. International Journal of Advanced Academic Research, 5(11), 139-160.

Bhat, F. M., \& Riar, C. S. (2017). Studies on effect of temperature and time on textural and rheological properties of starch isolated from traditional rice cultivars of Kashmir (India). Journal of Texture Studies, 48(2), 151-159. PMid:28370109. http://dx.doi.org/10.1111/jtxs.12226

Biro Pusat Statistik - BPS. (2016). Consumption expenditure of population of indonesia. Jakarta: Central Bureau of Statistics.

Couto, A., Enes, P., Peres, H., \& Oliva-Teles, A. (2012). Temperature and dietary starch level affected protein but not starch digestibility in gilthead sea bream juveniles. Fish Physiology and Biochemistry, 38(3), 595-601. PMid:21728054. http://dx.doi.org/10.1007/s10695-011-9537-5

Denchai, N., Suwannaporn, P., Lin, J., Soontaranon, S., Kiatponglarp, W., \& Huang, T. C. (2019). Retrogradation and digestibility of rice starch gels: the joint effect of degree of gelatinization and storage. Journal of Food Science, 84(6), 1400-1410. PMid:31132154.

Donald, A. M. (2004). Understanding starch structure and functionality. In A. Eliasson (Ed.), Starch in food. Sawston: Woodhead Publishing Limited. http://dx.doi.org/10.1533/9781855739093.1.156

Francisquini, J. A., Nunes, L., Martins, E., Stephani, R., Perrone, I. T., \& Carvalho, A. F. (2020). How the heat treatment affects the constituents of infant formulas: a review. Brazilian Journal of Food Technology, 23, e2019272. http://dx.doi.org/10.1590/1981-6723.27219

Hair, F., Anderson, J., Tatham, I., \& Black, C. (2005). Multivariate data analysis (5th ed.). New Jersey: Prentice Hall. Han, X. Z., \& Hamaker, B. R. (2001). Amylopectin fine structure and rice starches paste breakdown. Journal of Cereal Science, 34(3), 279-284. http://dx.doi.org/10.1006/jcrs.2001.0374

Haryanti, P., Setyawati, R., \& Wicaksono, R. (2014). Effect of temperature and time of heating of starch and butanol concentration on the physicochemical. Agritech, 34(3), 308-315. http://dx.doi.org/10.22146/agritech.9459

Indriati, A., Hidayat, D. D., Andriansyah, R. C. E., Iwansyah, A. C., \& Surahman, D. N. (2020). Characterisation of physical, mechanical and colour properties of Muntingia calabura fruits. In S. K. Wahono (Ed.), IOP Conference Series: Earth and Environmental Science: Vol. 462, No. 1. Tangerang: IOP Publishing. http://dx.doi.org/10.1088/1755-1315/462/1/012044

Jamilah, B., Mohamed, A., Abbas, K. A., Rahman, R. A., Karim, R., \& Hashim, D. M. (2009). Protein-starch interaction and their effect on thermal and rheological characteristics of a food system: a review. Journal of Food Agriculture and Environment, 7(2), 169-174.

Jang, E. H., Lee, S. J., Hong, J. Y., Chung, H. J., Lee, Y. T., Kang, B. S., \& Lim, S. T. (2016). Correlation between physicochemical properties of japonica and indica rice starches. Lebensmittel-Wissenschaft + Technologie, 66, 530-537. http://dx.doi.org/10.1016/j.Iwt.2015.11.001

Lan, X., Liu, X., Yang, Y., Wu, J., \& Wang, Z. (2017). The effect of lamellar structure ordering on the retrogradation properties of canna starch subjected to thermal and enzymatic degradation. Food Hydrocolloids, 69, 185-192. http://dx.doi.org/10.1016/j.foodhyd.2017.02.004

Li, H., Prakash, S., Nicholson, T. M., Fitzgerald, M. A., \& Gilbert, R. G. (2016). Instrumental measurement of cooked rice texture by dynamic rheological testing and its relation to the fine structure of rice starch. Carbohydrate Polymers, 146, 253-263. PMid:27112873. http://dx.doi.org/10.1016/j.carbpol.2016.03.045

Makame, J., Cronje, T., Emmambux, N. M., \& De Kock, H. (2019). Dynamic oral texture properties of selected indigenous complementary porridges used in African communities. Foods, 8(6), 221. PMid:31234403. http://dx.doi.org/10.3390/foods8060221

Mayachiew, P., Charunuch, C., \& Devahastin, S. (2015). Physicochemical and thermal properties of extruded instant functional rice porridge powder as affected by the addition of soybean or mung bean. Journal of Food Science, 80(12), E2782-E2791. PMid:26523755. http://dx.doi.org/10.1111/1750-3841.13118

Ministry of Health of Indonesia. (2019). Riset Kesehatan Dasar (Riskesdas). Jakarta: Ministry of Health of Indonesia

Muchlisyiyah, J., Prasmita, H. S., Estiasih, T., \& Nurfatimah, R. P. (2020). The effect of pregelatinization with heat and moisture treatment on physicochemical and pasting characteristics of red glutinous rice flour. Research Journal of Life Science, 7(3), 168-176. http://dx.doi.org/10.21776/ub.rjls.2020.007.03.7

Nunes, L. P., Ferrari, C. C., Ito, D., Souza, E. C. G., \& Germer, S. P. M. (2020). Drum drying process of jabuticaba pulp using corn starch as an additive. Brazilian Journal of Food Technology, 23, e2019166. http://dx.doi.org/10.1590/1981-6723.16619

Onyango, C., Luvitaa, S. K., Unbehend, G., \& Haase, N. (2020). Nutrient composition, sensory attributes and starch digestibility of cassava porridge modified with hydrothermally-treated finger millet. Journal of Agriculture and Food Research, 2, 100021. http://dx.doi.org/10.1016/j.jafr.2020.100021

Palguna, I. G. P. A., Sugiyono, S., \& Hariyanto, B. (2014). Karakteristik pati sagu yang dimodifikasi dengan perlakuan gelatinisasi dan retrogradasi berulang. Jurnal Pangan, 23(6), 146-156.

Puspitowati, S., \& Driscoll, R. H. (2007). Effect of degree of gelatinisation on the rheology and rehydration kinetics of instant rice produced by freeze drying. International Journal of Food Properties, 10(3), 445-453. http://dx.doi.org/10.1080/10942910600871289

Rohaya, M. S., Maskat, M. Y., \& Ma'ruf, A. G. (2013). Rheological properties of different degree of pregelatinized rice flour batter. Sains Malaysiana, 42(12), 1707-1714.

Singh, N., Kaur, L., Sandhu, K. S., Kaur, J., \& Nishinari, K. (2006). Relationships between physicochemical, morphological, thermal, rheological properties of rice starches. Food Hydrocolloids, 20(4), 532-542. http://dx.doi.org/10.1016/j.foodhyd.2005.05.003

Sopade, P. A., Ajisegiri, E. S., \& Badau, M. H. (1992). The use of peleg equation to model water absorption in some cereal grains during soaking. Journal of Food Engineering, 15(4), 269-283. http://dx.doi.org/10.1016/0260-8774(92)90010-4 
Effect of pre-gelatinized temperature on physical and nutritional content of indonesian instant cassava leaves porridge: rowe luwa Iwansyah et al.

United Nations International Children's Emergency Fund - UNICEF. World Health Organization - WHO.(2020). Malnutrition prevalence remains alarming: stunting is declining too slowly while wasting still impacts the lives of far too many young children. Retrieved in 2021, March 8, from https://data.unicef.org/topic/nutrition/malnutrition/

Wadchararat, C., Masubon, T., \& Naivikul, O. (2006). Characterization of pregelatinized and heat moisture treated rice flours. Witthayasan Kasetsat Witthayasat, 40, 144-153.

Wijanarka, A., Sudargo, T., Harmayani, E., \& Marsono, Y. (2017). Effect of pre-gelatinization on physicochemical and functional properties of gayam (Inocarfus fagifer forst.) flour. American Journal of Food Technology, 12(3), $178-185$. http://dx.doi.org/10.3923/ajft.2017.178.185

Zielinska, M., \& Markowski, M. (2012). Color characteristics of carrots: effect of drying and rehydration. International Journal of Food Properties, 15(2), 450-466. http://dx.doi.org/10.1080/10942912.2010.489209

Funding: Lembaga Ilmu Pengetahuan Indonesia (267/E1/PRN/2020) and Lembaga Pengelola Dana Pendidikan (KEP-32/LPDP/2020)

Received: Mar. 08, 2021; Accepted: Oct. 29, 2021

Section Editor: Mateus Petrarca 